\title{
Eukasz Mirocha
}

Uniwersytet Mikołaja Kopernika, Toruń

adwokat.mirocha@gmail.com

\section{Trzy modele obywatelstwa a edukacja publiczna}

DOI: http://dx.doi.org/10.12775/SIT.2016.023

Aż do lat 80. XX w., kiedy to na dobre rozgorzała dyskusja komunitarystów $z$ liberałami, pojęcie obywatelstwa nie budziło specjalnego zainteresowania filozofów polityki. Obywatelstwa używano - zgodnie $z$ jego prawnym znaczeniem - jako synonimu przynależności państwowej, ewentualnie praw i obowiązków z nią związanych. Spostrzeżenia komunitarystów uświadomiły wszystkim, że ramy instytucjonalne nie wystarczą do zapewnienia ładu społecznego. Istotne jest nastawienie członków społeczeństwa, chęć wspierania przez nich dobra wspólnego, utożsamianie się ze wspólnotą ${ }^{1}$. Potrzebna jest równowaga między prawami przysługującymi obywatelom a ich obowiązkami względem społeczeństwa. Dopiero ich suma określa status obywatela. Filozofia liberalizmu była bezradna wobec takich zjawisk jak apatia wyborcza (wszak ustawowy nakaz udziału w wyborach nie jest instrumentem liberalnym) czy nawet niechęć dla ochrony środowiska (dopóki nie zrozumiemy, że jest ono dobrem wspólnym, grozi nam tzw. tragedia pastwiska). Na skutek pluralizacji społeczeństw więzi narodowe nie mogły już na ogół odgrywać roli czynnika spajającego społeczeństwa, jak to miało

${ }^{1}$ W. Kymlicka, Wspótczesna filozofia polityczna, Warszawa 2009, s. 347-350. 
miejsce jeszcze kilkadziesiąt lat wcześniej² . Jednocześnie uprawnienia dawniej związane $z$ przynależnością państwową stopniowo ulegały internacjonalizacji na skutek rozwoju międzynarodowego prawa praw człowieka.

Praktyka społeczna pokazała, że nawet najlepsze przepisy prawne dla swej skuteczności wymagają co najmniej zrozumienia i akceptacji ich celu po stronie adresatów. By to osiągnąć, adresaci muszą partycypować w ich tworzeniu. Jest to jedno $\mathrm{z}$ podstawowych założeń teorii obywatelskiej, akcentującej wagę wolności pozytywnej czy idąc za Benjaminem Constantem - wolności starożytnych. Teoria obywatelska promuje model obywatelstwa zaangażowanego, partycypującego, słowem - republikańskiego ${ }^{3}$. Konkurencyjny wobec niej jest model liberalny. Tytuł artykułu mówi o trzech typach obywatelstwa. Trzeci $z$ nich to model komunitarystyczny (chociaż - o czym przekonamy się dalej - nieco na wyrost jest mówienie w jego kontekście o obywatelstwie). Od republikańskiego odróżnia go szczebel wspólnoty, na którym stara się budować poczucie więzi i promować cnoty. Republikanizmem określa się komunitaryzm państwowy ${ }^{4}$, przez komunitarystyczny model obywatelstwa rozumiem ten skupiający się na niewielkich, lokalnych wspólnotach, np. religijnych. W konkluzjach spróbuję ukazać, w jaki sposób, przyjęte na gruncie filozofii politycznej rozumienie obywatelstwa i jego modele mogą znajdować odzwierciedlenie w kształcie regulacji prawnych.

\section{Model liberalny}

Zacznijmy od modelu liberalnego, stanowi on bowiem dominujący wzór obywatelstwa w krajach Zachodu. Komunitaryzm, prezentując nierzadko radykalnie odmienne spojrzenie na kluczowe dla państwa i społeczeństwa sprawy, powstał jako alternatywa dla tego modelu.

2 Por. J. Habermas, Obywatelstwo a tożsamość narodowa. Rozważania nad przyszłościa Europy, przeł. B. Markiewicz, Warszawa 1993, s. 7.

${ }^{3}$ Por. Z. Osmólska, Obywatel a partycypacja. Próba delimitacji pojęcia partycypacji obywatelskiej, „Societas et Ius” 2013, nr 1, s. 52-55.

${ }^{4}$ Por.: L. Morawski, Podstawy filozofii prawa, Torun 2014, s. 114, 122; W. Kymlicka, op.cit., s. 363. 
Miał zapobiegać jego bolączkom, korygować wady indywidualizmu i hegemonii uprawnień. Zastrzec trzeba, iż zamieszczone w tym tekście uwagi bardziej odpowiadają obrazowi społeczeństwa bliskiemu myśli liberałów o poglądach zbliżonych do Friedricha Augusta von Hayeka czy Miltona Friedmana ${ }^{5}$ niż późnego Johna Rawlsa.

Dla liberała społeczeństwo to zbiór jednostek, które łączą się na zasadzie dobrowolności, kierowane własnym interesem w myśl zasady, że razem będzie można łatwiej, taniej, szybciej osiągnąć określone cele. Członków liberalnego społeczeństwa nie musi łączyć żadna więź etyczna, etniczna czy kulturowa ${ }^{6}$. Decydując się na wspieranie pewnych funkcji państwa, np. prowadzenie przez nie polityki społecznej, liberał nie kieruje się troską o najuboższych, lecz prywatnym interesem, który wyraża Rawlsowska zasada maksyminu. Wywodzący się od Johna Locke’a liberalny model przynależności cechuje indywidualizm i instrumentalne podejście do społeczeństwa. Obywatelstwo liberalne to członkostwo w organizacji. Bilans wkładu jednostki i wypłaty na jej rzecz musi być korzystny w utylitarnych kategoriach. Obywatel nie musi utożsamiać się z państwem, co nie przeszkadza mu wysuwać względem państwa określonych oczekiwań (wynika to $z$ liberalnej koncepcji uprawnień) ${ }^{7}$. Liberalny patriotyzm sprowadza się co najwyżej do patriotyzmu konstytucyjnego (wierności sprawiedliwym zasadom organizacji państwa), głębsze przywiązanie do państwa czy ludzi je zamieszkujących nie jest potrzebne ${ }^{8}$. Państwo jest jednak w pewnym stopniu czynnikiem integrującym. Występuje ono w roli regulatora relacji społecznych, jest „wyższą instancją”. Drugim, zdecentralizowanym, regulatorem relacji społecznych jest dla liberała rynek ${ }^{9}$. Właśnie rynek jest modelem kontaktów międzyludzkich, które bardziej przypominają targi niż współpracę. Podsumowując - liberał

${ }^{5}$ Szeroką polemikę z ich, czy szerzej - neoliberalnymi, postulatami przedstawia A. Szahaj, Liberalizm, wspólnotowość, równość. Eseje z filozofii polityki, Toruń 2012, s. 9-68.

${ }^{6}$ L. Morawski, Podstawy filozofii prawa, s. 123.

7 J. Habermas, Obywatelstwo a tożsamość narodowa, s. 14.

8 Ibidem, s. 17.

9 J. Habermas, Trzy normatywne modele demokracji, w: idem, Uwzględniając Innego. Studia do teorii politycznej, Warszawa 2009, s. 238. 
nie postawi znaku równości między państwem a społeczeństwem, budując zaś hierarchę wartości, na pierwszym miejscu umieści jednostkę, następnie społeczeństwo, na końcu państwo.

Paradygmat rynkowy dominuje też w liberalnie postrzeganej polityce. Jest ona walką o pozycję, rywalizacją o głosy wyborców, nie zaś dążeniem do osiągnięcia wspólnego dobra. Proces demokratyczny opiera się raczej na kompromisach zaangażowanych w niego stron niż osiąganiu konsensusu. Jest bardziej odnajdywaniem równowagi między różnymi interesami niż wydobywaniem wspólnych dla jego uczestników wartości ${ }^{10}$.

Wspomniałem już, że liberalny obywatel, nie czując potrzeby angażowania się $\mathrm{w}$ sprawy państwa, nie hamuje się przed występowaniem względem niego $z$ roszczeniami. Wynika to $z$ liberalnej koncepcji uprawnień traktowanych jako przynależne każdemu prawa naturalne niezależne od tego, czy znajdują oparcie w systemie prawa, czy nie. Uprawnienia i wolności liberalne mają przeważnie charakter negatywny, określą sferę nieingerencji państwa i wolnego wyboru jednostek. To prawa definiują status człowieka jako obywatela. Jak ujął to SN USA - obywatelstwo jest „prawem do posiadania praw" ${ }^{11}$.

Przedstawiona koncepcja społeczeństwa, praw, polityki służy z pewnością ochronie interesów jednostki, wiąże się jednak również z szeregiem negatywnych następstw. Jürgen Habermas pisze o „syndromie obywatelskiej prywaty i redukcji roli obywatela do sytuacji klienta organizacji”. Jest to tym dotkliwsze, im struktury państwa (coraz bardziej technokratyczne, kierujące się efektywnością jako wiodącym kryterium) upodabniają się do instytucji rynkowych, z pominięciem szerszego spojrzenia na dobro obywateli jako całości ${ }^{12}$. Jeśli jednostki nie odczuwają potrzeby troski o dobro wspólne, a nie przejawia jej także państwo, to brak jest w ogóle podmiotu odpowiedzialnego za tę wartość. Interes prywatny staje się probierczy we wszystkich sferach życia.

\footnotetext{
${ }^{10}$ Ibidem, s. 241, 244.

11 Za: W. Kymlicka, op.cit., s. 351.

12 J. Habermas, Obywatelstwo a tożsamość narodowa, s. 23.
} 
Krytycy liberalnego modelu obywatelstwa podnoszą, że winę za brak zaangażowania obywateli w sprawy publiczne - a w efekcie kolonizowanie tej sfery przez biurokrację i rządy ekspertów - ponosi tzw. agregacyjno-wyborczy model demokracji ${ }^{13}$. Sprowadza on rolę obywateli do biernych, oddających raz na kilka lat głos wyborców, którzy coraz rzadziej wierzą w możliwość wywierania wpływu na losy państwa. Mechanizm wyborczy zawsze stawia kogoś w roli przegranego, co rodzi poczucie wykluczenia i niemocy w zakresie spraw publicznych. Podważa tym samym legitymującą funkcję demokracji ${ }^{14}$. Odpowiedzią na tę bolączkę ma być model deliberacyjny, w którym zaangażowani w proces rządzenia obywatele przedstawiają racje na rzecz swojego stanowiska w języku zrozumiałym dla wszystkich uczestników debaty, przez co działają również w interesie publicznym. Deliberacja pozwala nawet stronie przegrywającej ostatecznie w głosowaniu zrozumieć powody porażki, podobnie jak przekonujące uzasadnienie wyroku pozwala go zaakceptować stronie procesu. Zauważmy jednak, iż deliberacja jest dla poszczególnych jednostek dużo większym ciężarem niż udział w wyborach raz na kilka lat. Obserwacja ta potwierdza tezę, że nawet doskonałe liberalne instytucje wymagają dla właściwego funkcjonowania określonej, zorientowanej na dobro wspólne, postawy obywateli. Wymagają cnót obywatelskich. Współczesny liberalizm dopiero zaczyna doceniać ich rolę w polityce, są one natomiast podstawą koncepcji republikańskiej. Zanim przejdę do jej omówienia, przyjrzyjmy się kształtowi liberalnej edukacji.

Zacznijmy od pewnej uwagi metodologicznej. W literaturze anglojęzycznej termin liberal education pojawia się jako oznaczenie humanistycznej opozycji dla nauczania zorientowanego praktycznie, odwołującego się do kryterium technicznej efektywności, skuteczności ${ }^{15}$. Pisząc dalej o nauczaniu czy edukacji liberalnej, mam na myśli kształcenie, które koresponduje z pryncypiami filozofii

${ }^{13}$ L. Morawski, Podstawy filozofii prawa, s. 136.

${ }^{14}$ W. Kymlicka, op.cit., s. 354.

15 Np.: Ch.H. Russell, Liberal education and the law, „Journal of Legal Education” 1958, vol. 11; J. Hall, Towards a liberal legal education, „Iowa Law Review” 1945, vol. 30. 
i praktyki liberalnej, co nie zawsze będzie pokrywało się z pierwszym wskazanym znaczeniem.

Liberalna edukacja będzie przygotowywała ucznia do życia w środowisku rządzonym przez prawidła rynku oraz będzie kładła nacisk na realizację jego autonomii. Liberalne kształcenie ma pokazywać, „jak myśleć”, a nie „co myśleć”. Wartości wspierane przez ten model edukacji to wyobraźnia, niezależność, kontestacja, samostanowienie. Wolny wybór jest wartością inherentną. W efekcie uczniowie mają z podejrzliwością podchodzić do argumentu $\mathrm{z}$ autorytetu, w cenie jest zdolność do porównywania i ważenia różnych opcji, bez odwołania do dogmatu tradycji. Podstawami edukacji liberalnej są neutralność, pluralizm ${ }^{16}$.

W liberalnym programie nauczania znajdzie się miejsce na zajęcia, których obecność sugeruje koniunktura rynkowa - matematykę, chemię, biologię, ale już niekoniecznie na nauczanie historii czy bogaty kurs literatury narodowej. Troska o realizację autonomii każe uświadamiać uczniów w zakresie edukacji seksualnej ${ }^{17}$, podczas gdy nauczanie religii może zostać uznane za naruszające sferę wolności ich albo ich rodziców ${ }^{18}$.

Oponenci twierdzą, że rezultatem tak zaprojektowanej edukacji może być zastąpienie niezależności myślenia egoizmem, odpowiedzialności w sferze seksualnej rozwiązłością. Nauka krytycznego czytania (critical reading) może prowadzić do rezultatów sprzecznych

${ }^{16}$ Por. J. Chafetz, Social reproduction and religious reproduction, „William and Mary Bill of Rights Journal” 2006, vol. 15, s. 267-270.

17 Por. wyrok ETPCz z 7 grudnia 1976 r. w sprawie Kjeldsen, Busk Madsen, Pedersen przeciw Danii, w którym Trybunał uznał, że obowiązkowa edukacja seksualna w szkołach publicznych nie narusza wolności religijnej dzieci i rodziców ani prawa rodziców do wychowania dzieci w zgodzie $z$ własnymi przekonaniami, pod warunkiem że zapewniona jest możliwość uzyskania zwolnienia z zajęć lub edukacji w szkołach prywatnych gdzie przedmiot ten był znacznie ograniczony.

${ }_{18}$ Por. wyrok ETPCz z 29 czerwca 2007 r. w sprawie Folgero i inni przeciw Norwegii, gdzie obowiązkowe nauczanie przedmiotu o nazwie „Chrześcijaństwo, religia i filozofia”, obejmującego elementy wykonywania chrześcijańskich praktyk religijnych, wobec braku jasnych reguł zwalniania uczniów - przy głosach sędziów 9 do 8 - zostało uznane za sprzeczne $z$ prawem rodziców do wychowania dzieci zgodnie $z$ ich przekonaniami. 
z zamierzonymi, gdy dziecko zamiast prezentować postawę otwartą na różne światopoglądy, zacznie kwestionować wszelkie autorytety łącznie $z$ pozycją rodziców. $Z$ ryzykiem wiąże się nauczanie negowania utartych poglądów, gdy nie prezentuje się w ich miejsce wartościowych alternatyw (a tego $z$ uwagi na wymóg neutralności światopoglądowej liberalne kształcenie nie może oferować). Wbrew intencjom zwolenników obowiązkowej edukacji liberalnej może ona mieć efekt uniformizujący. Nie będzie to już rezultat prostej polityki asymilacji, jak w dziewiętnastowiecznych Stanach Zjednoczonych, gdy katolickich czy żydowskich imigrantów „protestantyzowano”. Mam na myśli niezamierzoną zamianę amiszów ${ }^{19}$, świadków Jehowy, katolików, imigrantów z Europy Wschodniej, przybyszów z krajów Ameryki Łacińskiej w klientów McDonalda, widzów seriali, odbiorców popkultury, bezbarwną masę konsumentów, ignorujących przy tym życie wspólnoty i potrzebę udziału w życiu politycznym. Zmianę, przed którą przestrzegał m.in. Alasdair MacIntyre, a którą antycypował już 150 lat wcześniej Alexis de Tocqueville, pisząc w nieco dramatycznym tonie: „Kiedy próbuję sobie wyobrazić ten nowy rodzaj despotyzmu zagrażający światu, widzę nieprzebrane rzesze identycznych i równych ludzi, nieustannie kręcących się w kółko w poszukiwaniu małych i pospolitych wzruszeń, którymi zaspokajają potrzeby swojego ducha. Każdy z nich żyje w izolacji i jest obojętny wobec cudzego losu; ludzkość sprowadza się dla niego do rodziny i najbliższych przyjaciół; innych współobywateli, którzy żyją tuż obok, w ogóle nie dostrzega; ociera się o nich, ale tego nie czuje. Człowiek istnieje tylko w sobie i dla siebie i jeżeli nawet ma jeszcze rodzinę, to na pewno nie ma już ojczyzny"20.

Defekty liberalnej edukacji owocują brakiem zaangażowania obywateli w życie publiczne oraz ich konsumpcyjnym nastawieniem. W Stanach Zjednoczonych, demokracji, w której stale ścierają się ze sobą liberalna i republikańska wizja obywatelstwa, dostrzeżono

19 Głównie za sprawą zwolnienia z obowiązkowej publicznej edukacji powyżej czternastego roku życia 90\% amiszów pozostaje przy wyznaniu rodziców, podczas gdy 44\% pozostałych Amerykanów zmienia wyznanie; G. Raley, Yoder revised: why the landmark amish schooling could - and should - be overturned, „Virginia Law Review” 2011, vol. 97:3, s. 705.

${ }^{20}$ Cyt. za: R. Aron, Esej o wolnościach, Warszawa 1997, s. 126. 
je, dlatego wysuwane są postulaty prowadzenia law-related teaching oraz character teaching. W trakcie takiego kształcenia wpajane są zasady ustrojowe (suwerenności, rządów prawa, rozdziału kościoła od państwa) oraz wartości (patriotyzmu, poszanowania życia, wolności, równości). Obserwując rezultaty liberalnej edukacji, staje się jasne, że dla zachowania spójności społecznej niezbędne jest wpajanie uczniom cnót takich jak szacunek, współpraca, odpowiedzialność ch $^{21}$ Podczas gdy liberalizm traktuje je jedynie instrumentalnie, dla republikanizmu są one wartością samą w sobie.

\section{Model republikański}

W przeciwieństwie do liberałów republikanie zdają się utożsamiać pojęcia państwa i społeczeństwa. Republikanin jest obywatelem, członkiem wspólnoty politycznej. Podobnie jak inni komunitaryści i zgodnie $z$ wnioskami współczesnej socjologii, republikanie uważają, że wspólnota jest pierwotna względem jednostki ${ }^{22}$. Apologia życia publicznego i dezawuowanie sfery prywatnej jako dotkniętej atomizmem są również charakterystyczne dla myśli republikańskiej $^{23}$. W perspektywie republikańskiej państwo nie jest organizacją, lecz wspólnotą. Obywateli jednoczy coś więcej niż prywatny interes $\mathrm{w}$ realizowaniu razem pewnych celów, łączy ich poczucie solidarności, więź narodowa, wspólna kultura, religia czy wartości $^{24}$. Rolą państwa nie jest przede wszystkim ochrona uprawnień obywateli, jak to ma miejsce w modelu liberalnym, ale stworzenie

21 J.S. Leming, Civic virtue: common ground for character education and law-related education professionals, „Law Related Education” 1996, vol. 20:1, s. 32.

${ }^{22}$ P. Selznick, The idea of communitarian morality, „California Law Review” 1987, vol. 75, s. 447, http://dx.doi.org/10.2307/3480588.

${ }^{23}$ W. Kymlicka, op.cit., s. 360.

${ }^{24}$ L. Morawski, Podstawy filozofii prawa, s. 136. Warto mieć w pamięci wprowadzony przez Michaela Walzera podział na republikanizm starego typu z więzami językowymi, etnicznymi czy religijnymi jako spójnikiem społeczeństwa (model romantyczny) i republikanizm nowego typu - odwołujący się do bardziej abstrakcyjnych, politycznych wartości (model oświeceniowy). 
platformy dla „inkluzywnego procesu kształtowania opinii i woli, w którym wolni i równi obywatele dochodzą do porozumienia co do tego, jakie cele i normy leżą we wspólnym interesie wszystkich”25. Quentin Skinner, komentując pewien wycinek myśli republikańskiej, pisze, że „idealny rząd republiki powinien umożliwić każdemu indywidualnemu obywatelowi równe prawo udziału w procesie tworzenia prawa, co z kolei gwarantowałoby, że wszystkie działania legislacyjne należycie oddawałyby wyrażoną wprost zgodę każdego członka organizmu politycznego jako całości”26. Republikanie dostrzegają, że liberalny model obywatelstwa, często odwołujący się do bilansu korzyści i strat, nie potrafi wyjaśnić natury zobowiązań jednostki względem pozostałych członków społeczeństwa ${ }^{27}$. W tym celu niezbędne jest odwołanie się do poczucia więzi, przynależności, patriotyzmu.

Gloryfikacja życia publicznego przekłada się na stosunek republikanów do polityki. Jej paradygmatem nie jest rynek, ale rozmowa, $\mathrm{w}$ toku której uczestnicy dochodzą do porozumienia ${ }^{28}$. Celem jest nie kompromis, lecz konsensus. Przekonanie o możliwości jego osiągnięcia wynika $z$ tkwiącego $u$ podstaw myśli komunitarystów przeświadczenia, że ludzi więcej łączy, niż dzieli, odkrycie zaś tego jest potrzebne i możliwe. Nie może zatem dziwić, że udział w polityce, w życiu publicznym, jest postrzegany nie jako przykra konieczność, ale przywilej i wartość sama w sobie ${ }^{29}$. Świadomy obywatel posiada szereg cnót, które pozwalają i każą mu realizować się w ramach wspólnoty. Jest on zdolny do poświęceń na rzecz ogółu, jest patriotą, wykazuje przywiązanie do tradycji i religii, ceni dobro wspólne wyżej

${ }^{25}$ J. Habermas, Trzy normatywne modele demokracji, s. 240.

${ }^{26}$ Q. Skinner, Wolność przed liberalizmem, przeł. A. Czarnecka, Toruń 2013, S. 50 .

${ }^{27}$ Por. np. M.J. Sandel, Sprawiedliwość. Jak postępować słusznie?, przeł. O. Siara, Warszawa 2013, s. 279 i n. Próby wyjaśnienia w imieniu liberałów podejmuje się np. D. Gauthier, Liberalne indywiduum, w: Komunitarianie. Wybór tekstów, red. P. Śpiewak, przeł. P. Rymarczyk, T. Szubka, Warszawa 2004, s. 115-129.

28 J. Habermas, Trzy normatywne modele demokracji, s. 242.

${ }^{29}$ W. Kymlicka, op.cit., s. 359. 
niż interes prywatny ${ }^{30}$, nie jest roszczeniowy, szanuje prawa innych, jest gotowy do udziału w dialogu publicznym i posłużenia się racjami zrozumiałymi dla interlokutorów ${ }^{31}$.

Ideał zaangażowania obywatela w politykę i legislację ściśle wiąże się $z$ republikańską wizją praw. W modelu republikańskim najważniejszym $z$ nich jest prawo wyborcze. Ogólnie rzecz biorąc, wolności pozytywne, prawa „do” odgrywają w republikanizmie większą rolę niż wolności i prawa pojmowane negatywnie. Źródłem republikańskich uprawnień nie jest jakiś wyższy porządek czy prawo naturalne jak w liberalizmie. Obywatelowi przysługują tylko te prawa, które są wprost gwarantowane przez porządek prawny jego państwa ${ }^{32}$. Stąd niebagatelną wagę ma udział w jego tworzeniu, znajdujący swój początek właśnie w uprawnieniu do wybierania. O zwolennikach republikańskiej teorii neorzymskiej Skinner pisze: „zakładają generalnie, że wolność czy swoboda może być [...] wyrażona jako nieskrępowane korzystanie $z$ szeregu uprawnień obywatelskich" ${ }^{33}$. Wynika $\mathrm{z}$ tego, po pierwsze, że uprawnienia nie są niezależne od obywatelstwa, nie przysługują wszystkim, lecz tylko członkom wspólnoty. Po drugie, że katalog uprawnień określa wyłącznie prawo stanowione, nie porządek boski czy naturalny.

Zaletą współczesnego modelu republikanizmu demokratycznego jest na pewno zatarcie granicy między rządzącymi a rządzonymi, nieobecny jest tutaj podział na „my” i „oni”, społeczeństwo i elitę. Jest to model radykalnie egalitarystyczny i demokratyczny ${ }^{34}$.

Wśród jego wad umieszcza się nadmierny idealizm i nieprzystawalność do współczesnych realiów spluralizowanych społeczeństw. Habermas, obserwując koincydencję republikanizmu i nacjonalizmu, pyta, czy „republikańska koncepcja obywatelstwa stosuje się, w najlepszym razie, tylko do nieskomplikowanych stosunków wy-

${ }^{30}$ L. Morawski, Podstawy filozofii prawa, s. 130.

31 W. Kymlicka, op.cit., s. 352.

${ }^{32}$ Por. np. P. Pettit, Wolność republikańska, w: Współczesna filozofia polityczna. Wybór tekstów źródłowych, red. D. Pietrzyk-Reeves, B. Szlachta, Kraków 2003, s. 168 i n.

${ }^{33}$ Q. Skinner, op.cit., s. 43.

34 J. Habermas, Trzy normatywne modele demokracji, s. 242; idem, Obywatelstwo a tożsamość narodowa, s. 15. 
stępujących w etnicznie homogenicznej, przejrzystej, zintegrowanej przez tradycje i obyczaje wspólnocie?”35. Już teoretycy myśli neorzymskiej natrafili na ten problem, uświadamiając sobie, że wola ogółu to jedynie suma woli jednostek, te zaś nie muszą nawet po najbardziej wyczerpujących deliberacjach zgadzać się we wszystkich sprawach. Ucieczką od tego problemu miało być tworzenie możliwie małych organizmów państwowych - republik, co pozwoliłoby zachować ideały powszechnej partycypacji i zgody ${ }^{36}$. W realizacji ideałów republikańskich na poziomie państwa liberałowie widzą ryzyko zaprowadzenia opresyjnej tyranii większości, zwłaszcza gdy republikanizm ten oparty będzie o kryteria narodowe czy religijne ${ }^{37}$.

Republikanie zasadniczo zgadzają się z liberałami, że to szkoły publiczne winny być „wylęgarniami cnót”. Bywa bowiem, że kościoły, grupy sąsiedzkie czy nawet rodzina wpajają młodym ludziom wartości, które okazują się uciążliwe w sferze publicznej ${ }^{38}$. W takim razie, jakie są republikańskie obiekcje względem liberalnej edukacji? Trafnie wyraził je Henry Tam, pisząc: „Wspólnoty, które nie próbują systematycznie edukować młodych ludzi, by stali się skutecznymi obywatelami, ryzykują, że indywidualizm relatywistyczny automatycznie zdominuje ich światopogląd. Ponieważ młodym ludziom brak wskazówek, co należy zrobić dla dobra wszystkich, mogą oni z łatwością wyrosnąć w przeświadczeniu, że dany wybór jest tak samo trafny jak jakikolwiek inny, i że podejmując swe decyzje, nie są nic winni szerszej wspólnocie"39. Republikańska edukacja ma zapobiegać tym zmorom, opierając się na zasadach, które stanowią również fundament republikańskiego ustroju społecznego. Są nimi: egalitaryzm przy poszanowaniu różnych potrzeb poszczególnych

${ }^{35}$ Idem, Obywatelstwo a tożsamość narodowa, s. 19.

${ }^{36}$ B. Szlachta, Zapoznane dziedzictwo polityczne Zachodu?, w: Q. Skinner, op.cit., s. 17-19.

${ }^{37} \mathrm{~J}$. Rhee, Theories of citizenship and their role in the bilingual education debate, "Columbia Journal of Law and Social Problems" 1999, vol. 33, s. 50, 55.

38 W. Kymlicka, op.cit., s. 373.

${ }^{39}$ H. Tam, Komunitaryzm: nowy program polityczny i obywatelski, przeł. J. Grygieńć, A. Szahaj, Toruń 2011, s. 105. 
uczniów ${ }^{40}$, waga wspólnych dociekañ ${ }^{41}$, odpowiedzialność, nastawienie na ogólny rozwój obywatela, a nie jedynie przystosowanie go do wymogów rynku, wpajanie pozytywnych wartości (nie zaś dążenie do neutralności), przywiązanie do tradycji i dorobku poprzednich pokoleń ${ }^{42}$. Centralną wartością, również w kształceniu, nie ma być, jak w przypadku liberalizmu, niezależność i wolność, lecz przynależność i obowiązki z nią związane ${ }^{43}$.

Edukacja republikańska opiera się na wierze w to, że dzięki wspólnym deliberacjom (które mają stanowić element nauczania na równi $z$ tradycyjnymi wykładami) można dojść do porozumienia niemal we wszystkich sprawach. W ten sposób rozstrzygnięty zostaje problem konfliktu oczekiwań państwa i wolności rodziców do wychowania dzieci zgodnie $z$ ich przekonaniami. W modelu republikańskim rodzice nie mogą raczej liczyć na zwolnienia ich dzieci z zajęć $z$ uwagi na konflikt przekonañ ${ }^{44}$. Państwo również w ramach systemu edukacji zastrzega sobie prawo do oceny przekonań czy tradycji i wspierania tylko tych, które przeszły test „wspólnych dociekań” ${ }^{45}$, czyli takich - co podnieśliby złośliwi - które zyskały aprobatę większości. Niemniej republikanizm przywiązuje dużą wagę do rodziny jako źródła wartości. Broniąc jego założeń, powiedzieć można, iż każda ze wspólnot - rodzina, kościół, grupa sąsiedzka - ma być inkubatorem odmiennych wartości, jednakże szkoła publiczna wpajać ma najistotniejsze, bo niezbędne dla zachowania spójności całego społeczeństwa, cnoty polityczne.

W założeniu cały system edukacji ma być przesiąknięty opisanymi zasadami. Praktyka pokazuje, że edukacja obywatelska, jeśli

${ }^{40}$ Por. M. Walzer, Sfery sprawiedliwości. Obrona pluralizmu i równości, przeł. M. Szczubiałka, Warszawa 2007, s. 307-324.

${ }^{41}$ H. Tam, op.cit., s. 106-112.

42 J. Rhee, op.cit., s. 47-50.

${ }^{43}$ P. Selznick, op.cit., s. 454.

${ }_{44}$ Przykładem takiej praktyki jest - zaakceptowany przez ETPCz w wyroku z 18 grudnia 1996 r. w sprawie Valsamis przeciw Grecji - brak możliwości zwolnienia uczniów będących świadkami Jehowy z uczestnictwa w paradzie wojskowej z udziałem przedstawicieli Cerkwii Prawosławnej, co zdaniem skarżących świadków Jehowy naruszało ich wolność wyznania i prawo do wychowania dzieci zgodnie $z$ przekonaniami rodziców.

${ }^{45}$ H. Tam, op.cit., s. 120-124. 
już jest prowadzona, ogranicza się do wtrętów na temat historii własnego państwa, jego ustroju, podstaw prawa ${ }^{46}$. Za ojczyznę współczesnej edukacji obywatelskiej można uznać Stany Zjednoczone. Pierwotnie kształcenie obywatelskie było elementem polityki asymilacji kierowanej do imigrantów, obejmowało podstawy kultury White Anglo-Saxon Protestants z jej judeochrześcijańskimi, greckorzymskimi i anglosaskimi korzeniami. Aktualizowało to liberalne obawy dotyczące opresyjności republikańskiej edukacji. Obecnie, mimo że postulaty dotyczące edukacji obywatelskiej są minimalne i ograniczają się do prowadzenia przedmiotu w rodzaju Civics and government, w aż 30 stanach można ukończyć szkołę średnią bez podstawowego kursu z zakresu ustroju własnego państwa ${ }^{47}$.

\section{Model komunitarystyczny}

Jeśli przypomnimy sobie opis wspólnot np. zarysowany przez MacIntyre’a w jego słynnej książce Dziedzictwo cnoty, rolę cnót w tych wspólnotach, podkreślaną przez filozofa wagę dociekań prowadzonych w celu odkrycia wspólnej tożsamości, wówczas podział na republikanizm i komunitaryzm wyda nam się sztuczny. Jednak radykalny komunitaryzm szkockiego filozofa nie pozwalał mu wierzyć w budowę wspólnoty na poziomie państwa. Na tle zdegenerowanej cywilizacji Zachodu enklawy prawosławnych imigrantów czy Żydów jawią się jemu jako wzór społeczeństwa. Przyjmując właśnie perspektywę małej, izolowanej i religijnie definiowanej wspólnoty,

${ }^{46}$ Ale może też odnosić się do kształtowania środowiska szkolnego - ilustracją republikańskiej postawy jest nakaz eksponowania krucyfiksu w klasach włoskich szkół, por. wyrok Wielkiej Izby ETPCz z 18 marca 2011 r. w sprawie Lautsi i inni przeciw Włochom. Innym przykładem może być zakaz noszenia chust islamskich przez nauczycieli i uczniów w szkołach państw, które deklarują przywiązanie do zasady sekularyzmu, np. Francji, Szwajcarii czy Turcji, por. wyroki ETPCz: z 15 lutego 2001 r. w sprawie Dahlab przeciw Szwajcarii, z 10 listopada 2005 r. w sprawie Sahin przeciw Turcji, z 4 grudnia 2008 r. w sprawie Dogru przeciw Francji, czy też zwyczaj salutowania fladze przez uczniów w Stanach Zjednoczonych.

${ }^{47}$ Ch.N. Quigley, Civic education: recent history, current status, and the future, „Albany Law Review” 1999, vol. 62, s. 1426, 1431. 
chciałbym wskazać odmienności komunitaryzmu niskiego szczebla i republikanizmu.

W jednym z wystąpień MacIntyre stwierdził, że szkoła nie powinna odpowiadać za jak najlepsze dostosowanie dziecka do życia w otaczającym je świecie, ale raczej wpajać mu sprzeciw wobec jego wad $^{48}$. Podobnie argumentuje Stephen L. Carter, twierdząc w odniesieniu do rodziców, że powinni oni zaszczepić dzieciom postawę nonkonformistyczną, w przeciwnym razie edukacja publiczna wywrze na nich totalizujące piętno ${ }^{49}$. Na pierwszy rzut oka stanowisko to zbliżone jest do liberalnych twierdzeń na temat konieczności krytycznego podejścia do zastanej rzeczywistości. Różnica tkwi w tym, że niemal wszystko to, co MacIntyre określiłby mianem wad, w które skierowany winien być sprzeciw uczniów, liberalizm traktuje jako osiągnięcia ludzkości. Również republikanizm odmiennie postrzega rolę szkoły, traktując ją jako instrument budowania ogólnoobywatelskiej więzi. W tym miejscu ujawnia się różnica komunitaryzmu niskiego szczebla (którego zwolennikiem jest np. MacIntyre) i republikanizmu. Autor Dziedzictwa cnoty każe realizować pewne ideały w ramach zamkniętej, niewielkiej wspólnoty, republikanizm idealistycznie wierzy w ich krzewienie w skali państwa.

Przykładem komunitarystycznej wspólnoty, w której edukacja ma prowadzić do największego niedostosowania do życia w mainstreamie są amisze. Dysponują oni siecią prywatnych szkół, w których edukacja prowadzona jest nawet po ukończeniu przez uczniów czternastego roku życia i kształcenia publicznego ${ }^{50}$. Celem nauczania jest utrzymanie izolacji wspólnoty, krzewienie credo, w myśl którego zewnętrzny świat jest pełen nieprawości, zbawienie zaś, jako naczelny cel, możliwe jest tylko w ramach wspólnoty. Edukacja ta nie dostarcza instrumentów niezbędnych do życia we

${ }^{48}$ Cyt. za: A. Chmielewski, Wprowadzenie, w: A. MacIntyre, Krótka historia etyki, Historia filozofii moralności od czasów Homera do XX wieku, przeł. A. Chmielewski, Warszawa 1995, s. 10.

${ }^{49}$ Za: J. Chafetz, op.cit., s. 283.

50 Jest to pokłosie wyroku SN USA z 15 maja 1972 r. w sprawie Yoder przeciw Wisconsin, w której z powołaniem się na I Poprawkę do Konstytucji Stanów Zjednoczonych amisze wywalczyli możliwość zwalniania z obowiązkowej edukacji publicznej dzieci po ukończeniu 14 roku życia. 
współczesnym społeczeństwie, amisze mają czuć się „pielgrzymami i obcymi”" ${ }^{1}$. Współzawodnictwo, sukces mierzony ilością zarobionych pieniędzy, dokonania intelektualne nie stanowią dla amiszów wartości. Umniejszając znaczenie życia doczesnego, stawiają oni w ich miejsce dobrobyt wspólnoty, dobroć czy mądrość, niepojmowaną jednak jako wiedza techniczna ${ }^{52}$.

Republikanizm będzie przeciwny obecności wspólnot komunitarystycznych w rodzaju amiszów. Ich istnienie zagraża spójności obywatelskiego narodu (zarzut „bałkanizacji”), wymaga gwarancji praw zbiorowych, co godzi w egalitaryzm republikańskiego narodu. $Z$ kolei klasyczny liberalizm jest niewrażliwy na potrzeby zbiorowości, nie będzie zainteresowany „dotowaniem” wspólnot, gdyż w jego perspektywie to jednostka jest na pierwszym miejscu ${ }^{53}$. Nawet John Gray, przedkładający tolerancję nad autonomię, dostrzega ryzyko związane $z$ religijnie inspirowanym prywatnym szkolnictwem, wieszcząc, że może ono wychować pokolenia terrorystów ${ }^{54}$. Jak już wyżej wspominałem, wspólnoty pokroju amiszów - pragnące izolacji, nieingerujące w sprawy państwowe i niepróbujące narzucać swojego światopoglądu innym - znajdą natomiast miejsce w ustroju wyznaczanym prawidłami liberalizmu politycznego późnego Johna Rawlsa. Przychylny będzie dla nich również multikulturalizm.

\section{Konkluzje}

Na wstępie wspomniałem, iż obywatelstwo jest prawnym pojęciem, które w ciągu ostatnich dekad - choć w oderwaniu od swojego pierwotnego rozumienia - przeżywa swoisty renesans ${ }^{55}$. Przedstawione rozważania uświadamiają, jak pojemne może to pojęcie być, od każdorazowego ustrojo- i ustawodawcy będzie zaś zależało, jaką tre-

${ }^{51}$ G. Raley, op.cit., s. 688 i n., 709.

52 Cyt. za: J.D. Gordon III, Wisconsin v. Yoder and religious liberty, "Texas Law Review” 1996, vol. 74, s. 1237.

53 J. Rhee, op.cit., s. 58 i n.

${ }^{54}$ B. Polanowska-Sygulska, Rozmowa z Johnem Grayem, w: Oblicza liberalizmu, red. B. Polanowska-Sygulska, Kraków 2003, s. 61.

${ }_{55}$ Por. Z. Osmólska, op.cit., s. 52, przyp. 1. 
ścią - liberalną czy republikańską - je wypełni. Oczywiście zawarte w tekście uwagi o modelach odnoszą się do swego rodzaju typów idealnych, rzeczywistość społeczna zaś najczęściej będzie bardziej złożona. Na przykład w polskiej Konstytucji z 1997 r. znajdziemy zarówno elementy, które można potraktować jako próbę odwołania się do liberalnego modelu obywatelstwa (szeroki katalog praw i wolności wywodzonych $z$ „przyrodzonej i niezbywalnej godności człowieka”, przy ograniczonym zakresie obowiązków obywatelskich), jak i te o konotacji republikańskiej. $Z$ kolei wizja republikańska będzie realizowana w wersji republikanizmu oświeceniowego, nawiązującego do ideału tożsamości konstytucyjnej (zawarte w preambule sformułowanie „Naród Polski - wszyscy obywatele Rzeczypospolitej”), ale także republikanizmu romantycznego, odwołującego się do tradycji i pojęcia narodu etnicznego (zawarte w preambule invocatio Dei, art. 6 chroniący kulturę jako źródło tożsamości narodowej) ${ }^{56}$.

Odpowiedzi na problemy analizowane w tekście można poszukiwać również - a może przede wszystkim - w aktach prawnych niższej rangi. Przykładem niech będzie coraz bardziej popularne bezpośrednie odwoływanie się do głosu obywateli przy tworzeniu budżetów samorządowych. Uczy ono zaangażowania, troski o wspólne dobro i odpowiedzialności.

Mówiąc o obywatelstwie, nie sposób także zignorować faktu, iż na gruncie prawnym, staje się ono coraz bardziej archaiczne. Na skutek rozwoju międzynarodowego prawa praw człowieka czy przedsięwzięć takich jak Unia Europejska uprawnienia gwarantowane są mieszkańcom państw bez względu na istnienie specjalnej więzi w postaci obywatelstwa. Nie oznacza to jednak, iż przyjęte w tekście rozumienie obywatelstwa przestaje być przydatne. Znaczenie ma przecież, czy - nawet jako kosmopolici - w relacjach społecznych będziemy opierali się na solidarności czy raczej niezaangażowaniu i którą $z$ tych postaw będzie preferował ustawodawca.

${ }^{56}$ Por. L. Morawski, Opinia $w$ sprawie wniosku grupy posłów z dnia 9 listopada 2011 r. o wydanie zarządzenia nakazującego usunięcie krzyża łacińskiego, znajdującego się $w$ Sali posiedzeń Sejmu RP, „Zeszyty Prawnicze Biura Analiz Sejmowych" 2011, nr 4, s. 106 i n. 
Edukacja publiczna jest przy tym czynnikiem, który ma wciąż ogromny wpływ na kreowanie postaw obywatelskich i moim zdaniem powinna być traktowana jako służące po temu narzędzie. Jednym z jej celów winno być zapobieganie bolączkom, na które cierpią współczesne społeczeństwa, takim jak konsumpcjonizm, zatracenie poczucia przynależności i wzajemnych zobowiązań współobywateli. Cel ten winien jednak być realizowany w sposób wolny od indoktrynacji, prozelityzmu, tolerancyjny, $z$ odwołaniem do miękkich metod perswazji, nie zaś przymusu i opresji.

\section{STRESZCZENIE}

Trzy modele obywatelstwa a edukacja publiczna

Obywatelstwo na ogół postrzegane jest jako synonim przynależności państwowej i praw z nią związanych. Współczesna filozofia polityki prezentuje jednak co najmniej dwie alternatywne wizje obywatelstwa, $z$ których pierwsza odwołująca się do liberalizmu zakłada model społeczeństwa złożonego z autonomicznych jednostek, druga zaś - komunitarystyczna postrzega społeczeństwo jako wspólnotę. Wizje te przekładają się na pożądany przez ich zwolenników kształt państwa, w tym edukacji publicznej. Podczas gdy liberalna edukacja kładzie nacisk na niezależność, tolerancję, umiejętności niezbędne do poruszania się w warunkach wolnego rynku, republikanizm będzie widział w szkolnictwie narzędzie krzewienia cnót publicznych, kultywowania tradycji, budowania poczucia przynależności. Artykuł omawia słabe i mocne strony obydwu wizji obywatelskości i stojących za nimi modelu edukacji, wskazuje także na trzecią wizję, którą uosabiają wspólnoty niskiego szczebla, występujące $\mathrm{z}$ roszczeniem zwolnienia ich od obowiązkowej edukacji państwowej.

Słowa kluczowe: liberalizm; republikanizm; komunitaryzm; wspólnotowość; obywatelstwo; edukacja publiczna; filozofia polityczna

\section{SUMMARY}

Three models of citizenship and public education

Citizenship is commonly considered to be synonymous with the state membership and rights related to the state membership. However, modern 
political philosophy presents at least two contradictory visions of citizenship: the liberal and the communitarian. The first one sees society as an aggregate of autonomous subjects. The second one- tends to view it as a community. These visions result in different shapes of state organisation and of course different models of public education. While liberal vision of public education emphasises subject's self-determination, tolerance, and free market skills; republicanism regards public education as a tool for inculcating public virtues, traditions and building sense of belonging. In the paper strong and weak points of both liberal and republican visions of citizenship and models stemming from them are commented. The author presents also the third model of citizenship - so called - low-level communitarianism that represents the demand to exempt some members of a community from state-established education.

Keywords: liberalism; republicanism; communitarianism; citizenship; public education; political philosophy

\section{BIBLIOGRAFIA}

Aron R., Esej o wolnościach, Warszawa 1997.

Chafetz J., Social reproduction and religious reproduction, „William and Mary Bill of Rights Journal” 2006, vol. 15.

Habermas J., Obywatelstwo a tożsamość narodowa. Rozważania nad przyszłością Europy, przeł. B. Markiewicz, Warszawa 1993.

Habermas J., Uwzględniając Innego. Studia do teorii politycznej, Warszawa 2009.

Hall J., Towards a liberal legal education, „Iowa Law Review” 1945, vol. 30 .

Gordon III J.D., Wisconsin v. Yoder and religious liberty, "Texas Law Review" 1996, vol. 74 .

Komunitarianie. Wybór tekstów, red. P. Śpiewak, przeł. P. Rymarczyk, T. Szubka, Warszawa 2004.

Kymlicka W., Wspótczesna filozofia polityczna, Warszawa 2009.

Leming J.S., Civic virtue: common ground for character education and law-related education professionals, „Law Related Education” 1996, vol. 20:1.

MacIntyre A., Krótka historia etyki. Historia filozofii moralności od czasów Homera do XX wieku, przeł. A. Chmielewski, Warszawa 1995.

Morawski L., Opinia $w$ sprawie wniosku grupy posłów z dnia 9 listopada 2011 r. o wydanie zarządzenia nakazującego usunięcie krzyża łaciń- 
skiego, znajdującego się $w$ Sali posiedzeń Sejmu RP, „Zeszyty Prawnicze Biura Analiz Sejmowych” 2011, nr 4.

Morawski L., Podstawy filozofii prawa, Torun 2014.

Osmólska Z., Obywatel a partycypacja. Próba delimitacji pojęcia partycypacji obywatelskiej, „Societas et Ius” 2013, nr 1.

Polanowska-Sygulska B., Rozmowa z Johnem Grayem, w: Oblicza liberalizmu, red. B. Polanowska-Sygulska, Kraków 2003.

Quigley Ch.N., Civic education: recent history, current status, and the future, „Albany Law Review” 1999, vol. 62.

Raley G., Yoder revised: why the landmark Amish schooling could - and should - be overturned, „Virginia Law Review” 2011, vol. 97:3.

Rhee J., Theories of citizenship and their role in the bilingual education debate, "Columbia Journal of Law and Social Problems" 1999, vol. 33.

Russell Ch.H., Liberal education and the law, „Journal of Legal Education” 1958, vol. 11.

Sandel M.J., Sprawiedliwość. Jak postępować słusznie?, przeł. O. Siara, Warszawa 2013.

Selznick P., The idea of communitarian morality, "California Law Review” 1987, vol. 75, http://dx.doi.org/10.2307/3480588.

Skinner Q., Wolność przed liberalizmem, przeł. A. Czarnecka, Toruń 2013.

Szahaj A., Liberalizm, wspólnotowość, równość. Eseje z filozofii polityki, Toruń 2012.

Tam H., Komunitaryzm: nowy program polityczny i obywatelski, przeł. J. Grygieńć, A. Szahaj, Toruń 2011.

Walzer M., Sfery sprawiedliwości. Obrona pluralizmu i równości, przeł. M. Szczubiałka, Warszawa 2007.

Współczesna filozofia polityczna. Wybór tekstów źródłowych, red. D. Pietrzyk-Reeves, B. Szlachta, Kraków 2003. 
